\title{
Sciendo \\ INFORMATION QUALITY MANAGEMENT AND THE ASPECT OF PROFIT AND LOSS IN THE CUSTOMER SERVICE PROCESS
}

doi:10.2478/mape-2018-0068

Date of submission of the article to the Editor: $03 / 2018$

Date of acceptance of the article by the Editor: 07/2018

MAPE 2018, volume 1, issue 1, pp. 537-543

Dr inż. Justyna Żywiołek, PhD

Dr hab. inż. Robert Ulewicz, prof. PCz

Częstochowa University of Technology, Poland

\begin{abstract}
Risk management is an inseparable part of every organization's life. It should be an integral part of the strategy implemented in all of the organizations. The strategy should be constructed in such a way that the management of the risk functions not only as a system avoiding losses, but also allowing to perceive and use opportunities, and create new opportunities for the organization. The aim of the article is to demonstrate the necessity of analyzing the risk of information quality, which significantly affects the customer service process. This analysis was carried out on the basis of T. Kaczmarek's research, which specified the list of 46 elements of the sick enterprise. On its basis, the areas in which information about customer service were created were analyzed, which allowed to identify potentially threatened places and the effects of these threats. The analysis showed that the highest level of risk is related to the delivery time. Individual and corporate clients pay special attention to the lack, or incorrect information on securing the shipment. The lowest level of risk in the examined enterprise concerns the terms of technical assistance, because this item is usually described by the seller in the purchase regulations.
\end{abstract}

Keywords: risk management, customer service, quality, information, information flow

\section{INTRODUCTION}

Responsibility for the strategy, and risk management associated with it, should be taken also by the Supervisory Board. This body should constantly monitor the flow of information in the company, as well as its structure in the relation to the implementation of the strategy, and the way of risk management. The flow of information in manufacturing enterprises, especially in times of growing expectations and requirements of recipients and consumers, is very important. Intangible resources, to which information belongs undoubtedly, are now considered the most important assets of an enterprise. It is worth noting that information is also treated as one of the basic factors of production. It can therefore be concluded that it directly affects the development of enterprises, as well as building and ensuring competitive advantage (Kaczmarek, 2008; Ficoń, 2011; Rasmussen, 1997).

Uncertainty is a phenomenon threatening the efficient management of the enterprise. It affects all processes occurring not only within the organization, but also in the relations of the enterprise environment (Lisiecka, 2010; Santos-Vijande et al., 2007). A complex and permanently changing environment requires the company to adapt. The ability to adapt is an important element of the company's operation, which determines the manner and pace of minimizing uncertainty (Żywiołek, 2016; Reidenberg, 1998). It is, however, highly complicated, because the amount and variety of acting forces makes the their minimization difficult. Skilful coping with the uncertainty requires the company to achieve, collect, process and analyze relevant information, and then analyze and evaluate this phenomenon itself.

Business management should constitute activities limiting the undertaking of these projects, of which the outcome is uncertain. Lack of information necessary to make a decision or predict 
the consequences forces the entrepreneur to cease operations. The consequence of uncertainty is the risk, which is often limited to the occurrence of threats described by the probability of their occurrence. Uncertainty and risk are phenomena describing the quantity and quality of information possessed, as well as the variability of surrounding conditions.

The manners of coping with the uncertainty are identifying the sources of risk, determining the probability of its occurrence and possible minimization of its effects. Elimination of the uncertainty is possible due to the acquisition, collection, processing and use of both information and knowledge during the course of events (Jajuga, 2009). This means that the company is open to change, prepared for the occurrence of risks. It is also able to identify, filter information and interpret them, generating knowledge at the same time. The aim of the ability to respond to situations is to minimize risks (Białas, 2007; Jevremovic et al., 2017).

\section{RISK MANAGEMENT IN THE ENTERPRISE}

The risk is related to every human activity, and is an inseparable element of the business and private sphere of everyone who makes decisions regarding future. This term is used to determine the combination of the frequency or probability of occurrence of a specific event causing a threat, as well as the consequences related to this event (Prus, 2010; Skotnicka-Zasadzien and Midor, 2010). The risk is difficult to identify and various companies treat in different ways. Entrepreneurs identify significant risks as: loss of reputation, changes in the market, loss of a key supplier/ customer, increase in operating costs. Business owners agree that each economic activity involves risks, so it seems necessary to manage them. Risk management is a system in the enterprise, working at every level and in every company (Gajda, 2014; Zasadzien and Zarnovsky, 2018). The task of this system is to identify potential events in order to manage risk and guarantee the stability of the organization.Risk management is a process consisting of five co-existing elements (Kabus et al., 2015):

- internal environment,

- risk identification,

- control activities,

- information and communication,

- monitoring.

The organization of the risk management system requires defining general activities, defining processes, impacting processes on themselves, obtaining information and processes and controls to achieve a goal or a certain level (Jelonek, 2017). These elements have a direct impact on the level of the risk. Risk management and its reporting should be subjected to detailed control. However, it must work in such a way as not to disturb the work of the enterprise, but to support it. It is inevitable to inform employees about possible risks, so that they can take them into account when making decisions or actions. One of the objectives of risk analysis is the correct flow of information, taking into account their quality, availability and processing capacity. In the process of risk identification it is necessary to examine its impact on the implementation of the set goals which would serve to eliminate or minimize the effects of the risk.

For the efficient functioning of the risk management system in an enterprise, it is necessary to implement (Brzozowska et al., 2014):

- rules for reporting risks by employees,

- a reporting program of emerging situations for management,

- a strategy including the main principles of risk management,

- a training program for employees,

- tools for risk analysis,

- IT solutions for risk management.

The concept of the risk management model in an enterprise is presented by Figure 1. 


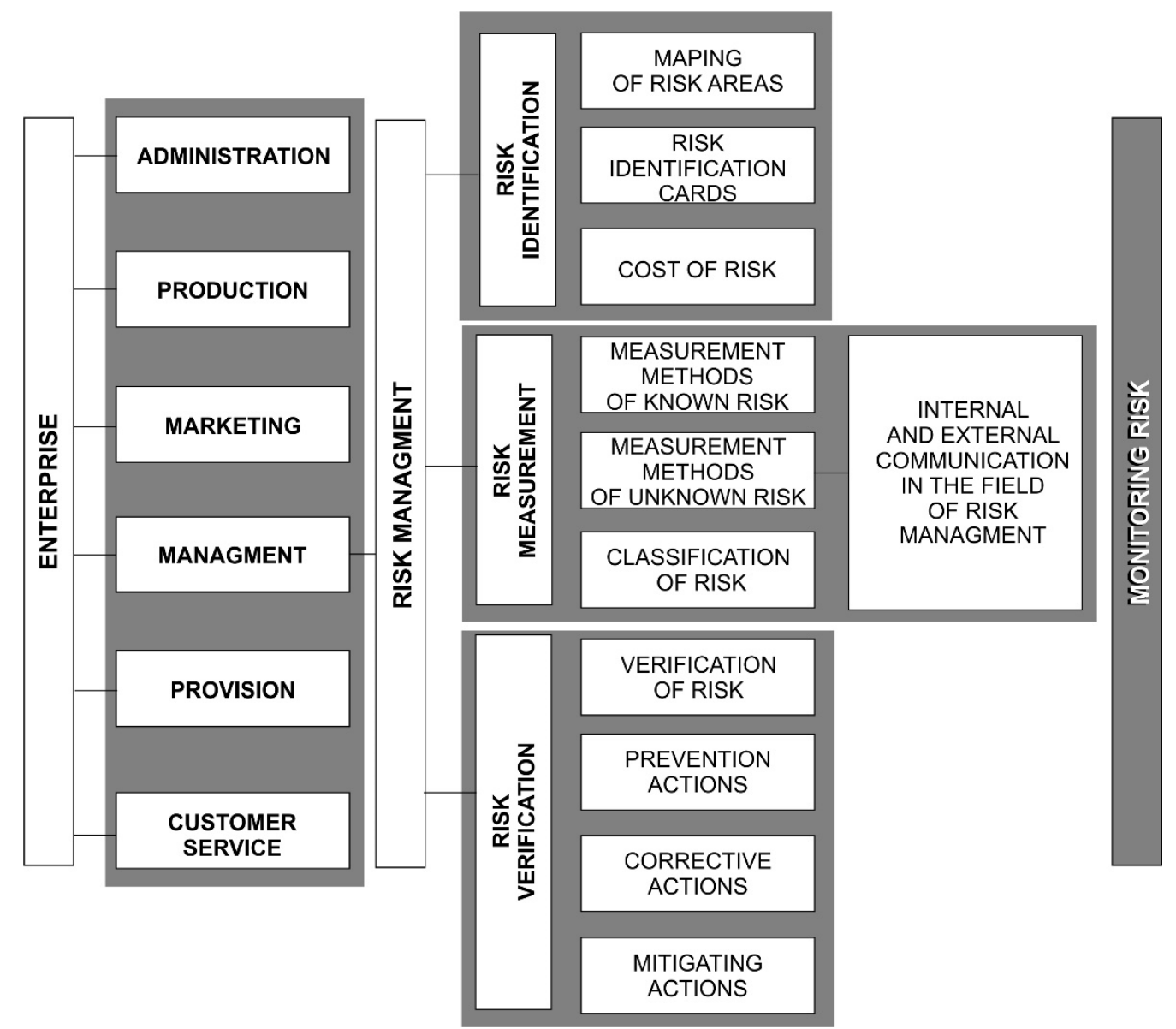

Fig.1. Flow of information on risk management in the enterprise

Source: based on (Jajuga, 2009).

Previous publications on managing the risk of mistakes made during customer service or communication errors. However, there is a lack of publications on issues related to risk and communication management during customer service. An information gap in this area is noticeable. Recognizing this problem is to improve customer service and reduce errors over time. Earlier publication concerns risk management or customer service process, however there are no publications linking these phenomena. Assessing the quality of information in the aspect of customer service is a difficult and long-lasting process.

\section{INFORMATION PROCESSED DURING CUSTOMER SERVICE}

Customer service is treated as an element related to satisfying the clients' needs. There is much information processed during the customer service, i.e. delivery time, its reliability, description of communication processes between the customer and the company, information about handling complaints. Delivery time is the period between placing an order until it is completed. Information relating to the delivery time affects the decision to make purchases. To obtain the effect of shorter time, electronic exchange of information between participants of the process is used.

Information about reliability is an assessment issued to the company by customers through opinions from friends, in social media, on the company's website or from websites created for the assessment of enterprises (Pacana and Ulewicz, 2017; Blaskova et. al., 2017). Reliability is also a certainty that the goods have been secured by the sender and will reach the customers in an intact condition. Another important element of customer service is communication, which means the flow of information between the participants of the purchasing process. 
An increasing number of companies use a solution consisting of informing the customer about individual stages of their order, e.g. it is accepted for realization, waiting for delivery, receiving the payment, sending . A large part of enterprises provide customers with the ability to track the place where the shipment is currently located online.

It is important to set or develop own standards to maintain a positive opinion about the company. In case of any doubts regarding the possibility of failure in meeting the standards or deficiencies, it is necessary to abandon it. Keeping it in spite of not maintaining it will result in choosing other company by the customers, or even giving up the purchase of the offered product.

Among the possible customer service standards there can be mentioned (Borowiecki and Czekaj, 2012):

- time of the order realization cycle,

- availability of individual inventory items,

- minimum size of the order,

- convenience of placing an order,

- frequency of deliveries,

- reliability of deliveries,

- quality of documentation,

- procedures related to handling complaints,

- completeness of orders,

- technical support conditions,

- status of order.

\section{ANALYSIS OF THE RISK OF INFORMATION PROCESSED DURING ORDER PROCESSING}

Recognizing the quality management of information as an element necessary for the proper customer service is a must. Incorrectly cataloging these data leads to financial losses in the form of lost clients.

The surveyed enterprise belongs to a group of large enterprises from the manufacturing and metallurgical industry. The company serves individual and corporate clients all over the world. The conducted analysis is a pilot study on information security risk management in manufacturing companies. The research was carried out in 2017, through a survey sheet of 86 employees. Only $30 \%$ were production workers, while the remaining part were logistics and direct customer service employees. As many as $5 \%$ of them were medium-sized management. Kaczmarek (2008) specified the list of threats to an enterprise conducting commercial or production activity. It includes 46 points of the so-called "sick" enterprise. The issues contained in them constituted the basis for the analysis of the information security risk of the examined enterprise.

As part of a direct interview with employees of the customer service department and scientific observations, in the analyzed company there noticed problem situations which could threaten the proper customer service (Table 1). Situations described there have been classified and grouped so as to pose threats to the company allowing to determine potential effects that may affect the level of information management in customer service. 
Table 1

Identified threats

\begin{tabular}{|c|c|c|c|c|}
\hline \multirow[b]{2}{*}{ No } & \multirow{2}{*}{$\begin{array}{l}\text { The element } \\
\text { of the } \\
\text { information } \\
\text { management } \\
\text { system }\end{array}$} & \multirow[b]{2}{*}{ Threats } & \multicolumn{2}{|c|}{ The level of threat } \\
\hline & & & $\begin{array}{l}\text { Individual- } \\
\text { customer }\end{array}$ & $\begin{array}{l}\text { Corporate- } \\
\text { customer }\end{array}$ \\
\hline 1 & \multirow{5}{*}{ 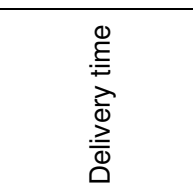 } & Delivery cycle time & 4 & 5 \\
\hline 2 & & Time of order service & 5 & 3 \\
\hline 3 & & Time of completing the order & 5 & 5 \\
\hline 4 & & Time to fill in gaps & 5 & 5 \\
\hline 5 & & No information exchange & 2 & 3 \\
\hline 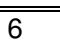 & \multirow{7}{*}{ 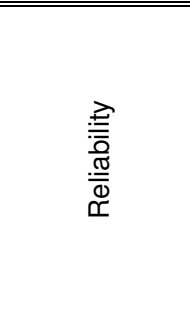 } & Failures of machines and devices & 2 & 2 \\
\hline 7 & & $\begin{array}{l}\text { No contact from the company's side after placing the } \\
\text { order }\end{array}$ & 5 & 4 \\
\hline 8 & & Inappropriate collateral for the order & 5 & 5 \\
\hline 9 & & Failures of the order service system & 4 & 1 \\
\hline 10 & & No choice of delivery method & 3 & 1 \\
\hline 11 & & Lack of the convenience of placing orders & 2 & 1 \\
\hline 12 & & Completeness of orders & 3 & 4 \\
\hline 13 & \multirow{7}{*}{ 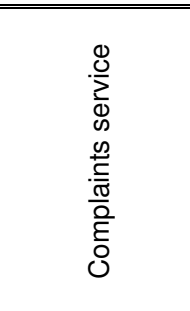 } & Difficulty of the complaint procedure & 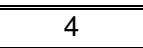 & 2 \\
\hline 14 & & Time of complaint handling & 3 & 2 \\
\hline 15 & & The way of dealing with complaints & 4 & 2 \\
\hline 16 & & The way of informing the customer & 2 & 2 \\
\hline 17 & & Documentation & 1 & 4 \\
\hline 18 & & Technical supportconditions & 1 & 1 \\
\hline 19 & & $\begin{array}{l}\text { Flow of information about complaints between } \\
\text { employees }\end{array}$ & 1 & 1 \\
\hline 20 & \multirow{4}{*}{ 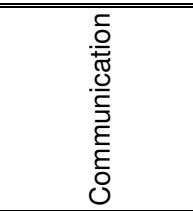 } & Communication between employees & 2 & 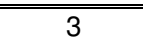 \\
\hline 21 & & Communication between the company and suppliers & 1 & 1 \\
\hline 22 & & Communication with the company transporting orders & 2 & 3 \\
\hline 23 & & Communication between the company and the customer & 4 & 4 \\
\hline
\end{tabular}

The threats detailed in Table 1 influence the functioning of information processes in the enterprise to a different extent. However, it should be emphasized that these are pilot studies, which is why they present only a part of problems related to information management. Special attention was paid to the service of individual and corporate clients' orders. In addition to identifying threats and their vulnerabilities, while creating an information risk management system there should be identified their causes and the possibilities of their elimination or minimization of their effects.

The analysis involves the preparation of a risk identification card, which is used primarily to collect information on the types of risks. The next stage of testing the level of threats should be the assessment using the risk identification card. The fragment of such a card is presented as a form which should be completed by the person managing the risk in the enterprise (Table 2).

Prepared data analysis allowed to determine the size of risks. They affect negatively on the flow of information in the company during the order service.

The highest level of risk is related to the delivery time. Individual and corporate clients agree that the most common problem is the lack, or incorrect information on securing the shipment. The lowest level of risk in the examined enterprise is related to technical support conditions, because this item is usually described by the seller in the purchase regulations. 
Table 2

Analysis of threats

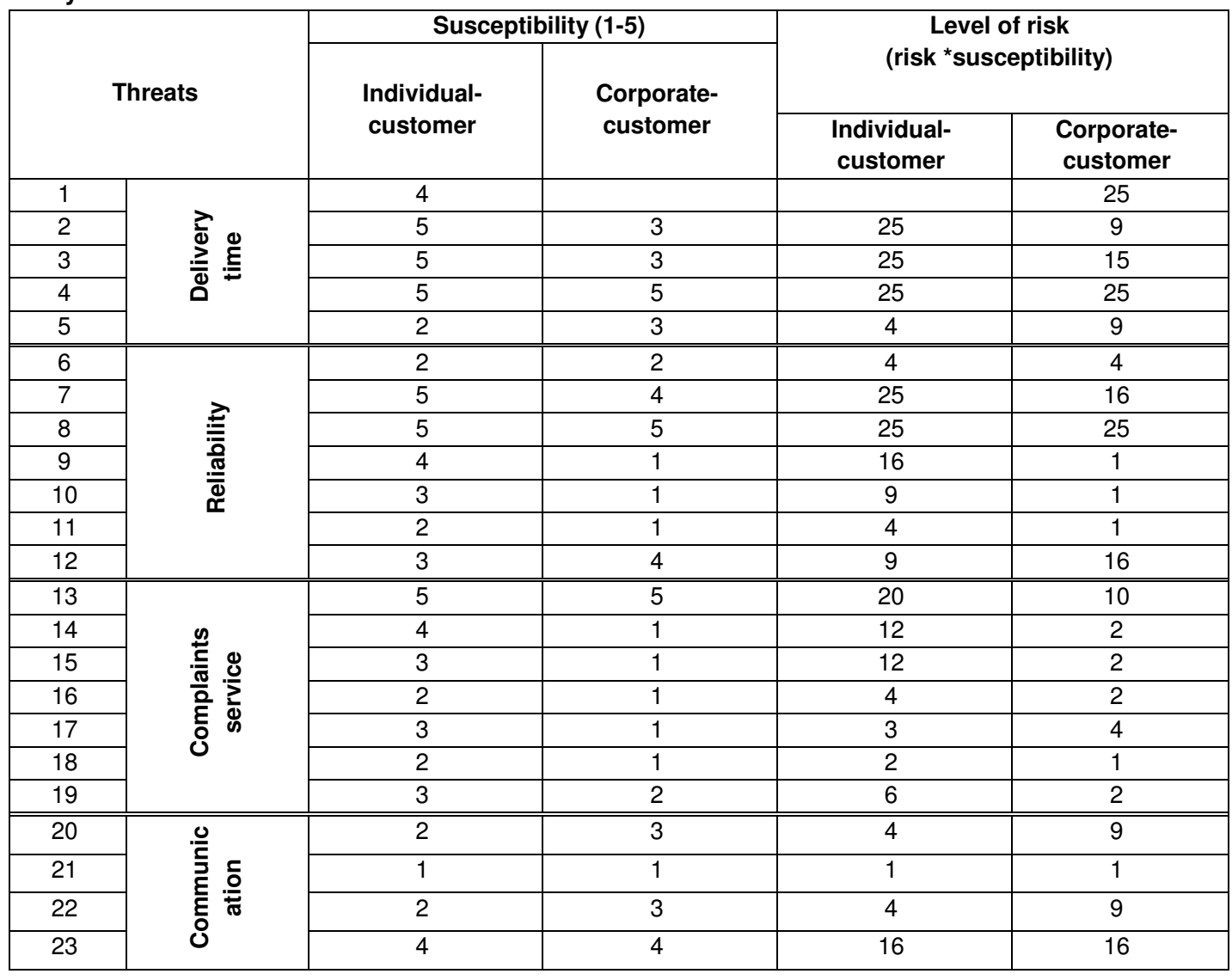

\section{CONCLUSION}

Risk management should be the subject of not only identifying the risk occurring during all information and decision processes in the enterprise. For the safety of the entire customer service process it is also important to direct the strategy of action in order to protect the risk elimination. The aim of the risk management should be to learn about possible threats and minimize their occurrence. As part of the pilot studies carried out, the author applied a list proposed by T. Kaczmarek, allowing identification of the main organizational problems in the examined manufacturing company and detailed their potential impact on the logistics system of the production company. The conducted research allows to make an assessment that the lack of proper information flow during the customer service process significantly reduces its level and may cause loss of clients.

\section{REFERENSES}

Białas, A. (2007). Bezpieczeństwo informacji i usług w nowoczesnej firmie. Warszawa: WNT.

Blaskova, M., Blasko, R., Rosak-Szyrocka, J. and Ulewicz, R. (2017). Flexibility and Variability of Motivating Employees And Managers in Slovakia and Poland. Polish Journal of Management Studies, 1(15), pp.26-36.

Borowiecki, R., Czekaj, J. (2012). Zarządzanie informacją i komunikacją w organizacjach gospodarczych. Toruń: TNOiK.

Brzozowska, A., Bubel, D., Pabian, A. (2014). Implementation of Technical and Information Systems in Environmental Management. Procedia - Social and BehavioralSciences,13, pp. 124-128.

Ficoń, K. (2011). Logistyka Ekonomiczna, procesy logistyczne. Warszawa: BEL Studio.

Gajda, J. (2014). Competence Management in the Process of Creating the Value of the Organization. Wydawnictwo Vydavatel'stvo EKONOM.

Jajuga, K. (2009). Zarządzanie ryzykiem. Warszawa: BEL Studio.

Jelonek, D. (2017). Big Data Analytics in the Management of Business, MATEC Web of Conferences, 125, 4 October 2017, Available at: https://www.matec- 
conferences.org/articles/matecconf/abs/2017/39/matecconf_cscc2017_04021/matecconf_cscc2 017_04021.html [Accessed 30 Jan. 2018].

Jevremovic, A., Veinovic, M., Shimic, G. (2017). An Overview of Current Security and Privacy Issues in Modern Telecommunications, $13^{\mathrm{TH}}$ International Conference on Advanced Technologies, Systems and Services in Telecommunications (TELSIKS), Proceedings Paper, pp. 119-123.

Kabus, J., Szymczyk, K., Sałek, R. (2015). It Authorisation of the Process of Knowledge Management, 2015 4th International Conference on Social Sciences and Society (ICSSS 2015), Pt 1, Advances in Education Research, (70), pp.106-112.

Kaczmarek, T.T. (2008). Ryzyko i zarządzanie ryzykiem. Ujęcie interdyscyplinarne, Warszawa: Difin.

Lisiecka, K. (2010). O zarządzaniu organizacjami w warunkach nieoczekiwanych, Kierunki i dylematy rozwoju nauki i praktyki zarządzania przedsiębiorstwem, Lichtarski J., Jagoda H. (ed.). Wrocław: UE we Wrocławiu.

Pacana, A.; Ulewicz, R. (2017). Research of determinants motiving to implement the environmental management system, Polish Journal of Management Studies, 1(16), pp. 165-174.

Prus, A (2010). Implementation and Functioning Integrated of Quality Management System and Industrial Safety System. TRANSCOM. 4-th European Conference of Young Research and Science Workers in Transport and Telecommunications. Proceedings. Section 4. Żilina.

Rasmussen, J. (1997). Risk management in a dynamic society: A modelling problem. Safety Science, 23 (27), pp.183-213.

Reidenberg, J.R. (1998). Lex informatica: The formulation of information policy rules through technology. Texas Law Review, 3(76), pp. 553-593.

Santos-Vijande, M.L., Alvarez-Gonzalez, L.I. (2007). Innovativeness and organizational innovation in total quality oriented firms: The moderating role of market turbulence. Technovation, 9(27). pp.514-532.

Skotnicka-Zasadzien, B., Midor, K. (2010). The effect of balanced development idea on the quality of life of inhabitants in selected municipalities of the Silesian province. Quality \& Quantity, 6(44), pp.1219-1226.

Zasadzien, M., Zarnovsky, J. (2018). Improvement of Selected Logistics Processes Using Quality Engineering Tools, Management Systems in Production Engineering, 1(26), 55-59.

Żywiołek J. (2016), The Policy Information as a Determinant of Security in the Supply Chain. Zakopane: Carpathian Logistics Congress, pp. 77-81. 